\title{
Cardiovascular Magnetic Resonance in Myocarditis
}

\author{
Christian L. Polte 1,2,3,*(D), Emanuele Bobbio ${ }^{3,4}$, Entela Bollano ${ }^{3,4}$, Niklas Bergh ${ }^{3,4}$, Christina Polte ${ }^{1,5}$, \\ Jakob Himmelman ${ }^{6,7}$, Kerstin M. Lagerstrand ${ }^{6,7}$ and Sinsia A. Gao ${ }^{1,3}$
}

1 Department of Clinical Physiology, Sahlgrenska University Hospital, 41345 Gothenburg, Sweden; christina.linke@vgregion.se (C.P.); sinsia.gao@vgregion.se (S.A.G.)

2 Department of Radiology, Sahlgrenska University Hospital, 41345 Gothenburg, Sweden

3 Institute of Medicine, The Sahlgrenska Academy at the University of Gothenburg, 41390 Gothenburg, Sweden; emanuele.bobbio@vgregion.se (E.B.); entela.bollano@vgregion.se (E.B.); niklas.bergh@vgregion.se (N.B.)

4 Department of Cardiology, Sahlgrenska University Hospital, 41345 Gothenburg, Sweden

5 Paediatric Heart Centre Gothenburg, Queen Silvia Children's Hospital, Sahlgrenska University Hospital, 41650 Gothenburg, Sweden

6 Department of Medical Physics and Biomedical Engineering, Sahlgrenska University Hospital, 41345 Gothenburg, Sweden; jakob.himmelman@vgregion.se (J.H.); kerstin.lagerstrand@vgregion.se (K.M.L.)

7 Institute of Clinical Sciences, The Sahlgrenska Academy at the University of Gothenburg, 41390 Gothenburg, Sweden

* Correspondence: christian.polte@vgregion.se; Tel.: +46-31-3421000

\section{check for}

updates

Citation: Polte, C.L.; Bobbio, E.

Bollano, E.; Bergh, N.; Polte, C.;

Himmelman, J.; Lagerstrand, K.M.; Gao, S.A. Cardiovascular Magnetic Resonance in Myocarditis.

Diagnostics 2022, 12, 399.

https://doi.org/10.3390/

diagnostics12020399

Academic Editors: Lukasz Malek,

Łukasz Mazurkiewicz and

Joanna Petryka-Mazurkiewicz

Received: 9 January 2022

Accepted: 30 January 2022

Published: 3 February 2022

Publisher's Note: MDPI stays neutral with regard to jurisdictional claims in published maps and institutional affiliations.

Copyright: () 2022 by the authors. Licensee MDPI, Basel, Switzerland. This article is an open access article distributed under the terms and conditions of the Creative Commons Attribution (CC BY) license (https:/ / creativecommons.org/licenses/by/ $4.0 /)$.

\begin{abstract}
Myocarditis is an inflammatory disease of the myocardium, and its diagnosis remains challenging owing to a varying clinical presentation and broad spectrum of underlying aetiologies. In clinical practice, cardiovascular magnetic resonance has become an invaluable non-invasive imaging tool in the evaluation of patients with clinically suspected myocarditis, mainly thanks to its unique multiparametric tissue characterization ability. Although considered as useful, the method also has its limitations. This review aims to provide an up-to-date overview of the strengths and weaknesses of cardiovascular magnetic resonance in the diagnostic work-up of patients with clinically suspected myocarditis in a broad clinical context.
\end{abstract}

Keywords: myocarditis; inflammatory cardiomyopathy; magnetic resonance imaging

\section{Introduction}

The diagnosis of myocarditis, defined as an inflammatory disease of the myocardium [1], remains challenging owing to its heterogeneity of clinical presentation and broad spectrum of underlying aetiologies [2]. Most frequently, myocarditis is caused by viral infections or other infectious agents, but can also be due to less common causes such as systemic diseases, drugs, or toxins [3,4]. Although mild forms usually resolve spontaneously, myocarditis can also lead to the development of end-stage heart disease owing to a dilated cardiomyopathy [5] or sudden cardiac death [6]. The reference standard for establishing the diagnosis of myocarditis is still endomyocardial biopsy (EMB), although this method faces several limitations, mainly due to its invasive nature, infrequent clinical use, and overall low sensitivity $[2,7,8]$. In clinical practice, cardiovascular magnetic resonance (CMR) has emerged as a useful non-invasive alternative thanks to its unique multiparametric tissue characterization ability [7]. CMR not only provides diagnostic information concerning the presence of myocardial inflammation [9], but also conveys prognostic information $[10,11]$. The current position statement regarding myocarditis from the European Society of Cardiology (ESC) Working Group on Myocardial and Pericardial Diseases [2], the ESC Guidelines for acute and chronic heart failure [12], as well as the scientific statement concerning specific dilated cardiomyopathies from the American Heart Association [13] consider CMR a useful method in patients with clinically suspected myocarditis. Despite being useful, CMR faces several limitations, which have to be taken into account in the clinical decision-making process. 
Accordingly, the aim of this review is to provide an up-to-date overview of the strengths and weaknesses of CMR in the diagnostic work-up of patients with clinically suspected myocarditis in a broad clinical context.

\section{Clinically Suspected Myocarditis}

\subsection{Clinical Presentation}

Myocarditis can affect patients of all ages, although different underlying aetiologies have their own characteristic age spectrum. In Western countries, most patients suffering from myocarditis are predominantly younger individuals, as most cases are caused by viral infections $[2,14]$.

The spectrum of clinical symptoms is rather wide and unspecific, ranging from mild discomfort due to palpitations, non-specific chest pain, or fatigue to more severe clinical manifestations such as acute coronary syndrome-like presentations, acute (with or without cardiogenic shock) or chronic heart failure, brady- and tachyarrhythmias, as well as conduction abnormalities $[15,16]$. Infectious prodrome with fever, myalgia, and respiratory or gastrointestinal symptoms can be present in cases of infectious myocarditis, whereas in other cases, symptoms associated with systemic diseases can be of relevance. Owing to the unspecific nature of clinical presentation, many cases of myocarditis may go undetected, are accidentally discovered during autopsy, or are discovered too late when the patient already developed end-stage heart disease [17].

\subsection{Diagnostic Work-Up}

In 2013, the ESC Working Group on Myocardial and Pericardial Diseases proposed new diagnostic criteria to improve the recognition of myocarditis in clinical practice (Table 1) [2] Hereby, it should be kept in mind that these recommendations were mainly based on viral myocarditis, but can also be extended to other underling aetiologies. Overall, the evaluation of patients with clinically suspected myocarditis is often quite extensive, as multiple differential diagnoses must be considered owing to the frequently unspecific clinical presentation. Furthermore, neither a single clinical nor diagnostic finding can presently confirm or exclude the diagnosis of myocarditis with absolute certainty, which is the reason for using an integrative diagnostic approach [18]. In addition to the clinical history and physical examination, the following diagnostic methods can be of value in the diagnostic work-up of patients with clinically suspected myocarditis:

A 12-lead electrocardiogram is usually pathologic in patients with myocarditis. However, the diagnostic value is rather limited, as the observed electrocardiographic changes are neither specific nor sensitive enough to allow a definite diagnosis $[2,7,19]$.

Biomarkers of myocardial injury (for instance, troponin T or I) and inflammation (for instance, C-reactive protein) can be elevated depending on the severity of inflammation and the timing of the test with respect to the natural course of the disease [20,21]. However, these biomarkers are rather unspecific. In clinical routine, viral testing is generally not recommended because of its unreliability [22].

Echocardiography is an established first-line imaging tool and shows frequently normal or unspecific findings in patients with myocarditis $[2,23]$. However, echocardiography can help to rule-out other differential diagnoses and is most likely useful for longitudinal follow-up studies, if clinically indicated. A potentially valuable addition is speckle-trackingderived strain, which might aid in the detection of an acute myocarditis [24-26].

A non-invasive coronary computed tomography angiography or invasive coronary angiography is frequently performed in patients with an acute coronary syndrome-like presentation, as well as in other clinical scenarios where it is necessary to rule-out eventual underlying coronary artery disease. Young patients with a classic history consistent with acute myocarditis and no cardiovascular risk factors may be able to obviate a coronary angiography, if immediate access to CMR is available [7]. 
Table 1. Diagnostic criteria for clinically suspected myocarditis.

Clinical presentation *

- Acute chest pain, pericarditic, or pseudo-ischemic

- New onset (days up to 3 months) or worsening of dyspnoea at rest or exercise, and/or fatigue, with or without left and/or right heart failure signs

- Subacute/chronic (>3 months) or worsening of dyspnoea at rest or exercise, and/or fatigue, with or without left and/or right heart failure signs

- Palpitation, and/or unexplained arrhythmia symptoms and/or syncope, and/or aborted sudden cardiac death

- Unexplained cardiogenic shock

Diagnostic criteria

1. ECG/Holter/Stress test features

- New findings (any of the following): atrioventricular block I-III, bundle branch block, ST-segment and T-wave alterations, reduced $\mathrm{R}$ wave height, abnormal $\mathrm{Q}$ waves, low voltage, sinus arrest, frequent premature beats, supraventricular tachycardia, ventricular tachycardia or fibrillation, and asystole

2. Biomarkers of myocardial injury

- $\quad$ Elevated troponin I or T

3. Cardiac imaging

- Echocardiography/Angiography

New regional wall motion or global systolic or diastolic function abnormality, with or without ventricular dilatation, with or without increased wall thickness, with or without pericardial effusion, with or without endocavitary thrombi

- Cardiovascular magnetic resonance

New regional wall motion or global systolic or diastolic function abnormality, with or without ventricular dilatation, with or without increased wall thickness, with or without pericardial effusion, with or without endocavitary thrombi

Oedema, and/or hyperaemia, and/or late gadolinium enhancement of classic myocarditic pattern

Clinically suspected myocarditis if $\geq 1$ clinical presentation and $\geq 1$ diagnostic criteria from different categories in the absence of (1) angiographically detectable coronary artery disease (coronary stenosis $\geq 50 \%$ ); (2) known pre-existing cardiovascular disease or extra-cardiac causes that explain the symptoms (for instance, valve disease, congenital heart disease, hyperthyroidism, and so on). The suspicion increases with higher numbers of fulfilled criteria. * If the patient is asymptomatic, $\geq 2$ diagnostic criteria should be met. Adapted and modified with permission from Caforio et al. [2].

Fluorine-18 fluorodeoxyglucose positron emission tomography/computed tomography can visualize myocardial inflammation and has become a valuable tool in the complicated diagnostic work-up of patients with clinically suspected cardiac sarcoidosis (CS) as well as their follow-up [27-31]. The method might also be useful in other complicated cases with inconclusive CMR and/or EMB, as for instance in recurrent myocarditis.

Endomyocardial biopsy is currently considered as a reference standard for the diagnosis of myocarditis based on established histological, immunological, and immunohistochemical criteria [1,32]. If performed according to the current indications [33] and in the hands of an experienced operator, EMB has a very low complication rate of $<1 \%$ [34]. However, the major limitations of EMB are its invasive nature, infrequent clinical use, and overall low sensitivity due to the methods' sampling limitations and the focal nature of inflammatory cell infiltration. The reported sensitivity is highest in giant cell myocarditis (GCM; approximately 80 to $93 \%$ with repeated biventricular sampling), but is much lower in other forms such as lymphocytic myocarditis and CS (estimated to be approximately 20 to $30 \%)[8,35,36]$. These limitations of the current reference standard are not merely a clinical problem, but also an impediment for the introduction of every new diagnostic test, because any difference between the two methods will be held against the new test and not the reference standard. 


\section{CMR Imaging of Myocardial Inflammation}

CMR can detect changes caused by myocardial inflammation independent of the underlying aetiology, and has thereby altered the clinical decision-making process of many patients $[7,18,37]$. The strength of the method lies in its unique multiparametric tissue characterization ability, which, however, relies mainly on parameters exploiting changes in extracellular volume to visualize myocardial inflammation. These visualized aspects of myocardial inflammation are oedema, hyperaemia, capillary leak, necrosis, as well as fibrosis. The extent and intensity of these changes depend on the degree of the underlying myocardial inflammation and the timing of the CMR study in relation to the natural course of the disease, as it progresses from an acute and subacute to a healed or chronic state. This temporal evolution of myocardial inflammation, which often lasts days to weeks before it frequently resolves, limits the optimal sensitivity for diagnostic imaging to only a few weeks from its presentation [38,39]. Thus, it is favourable to perform CMR imaging in the early stage of the disease. Consequently, this may also be the reason CMR performs best in patients with recent onset of angina-like symptoms, but is rather insufficient in patients with heart failure or arrhythmias as their primary symptom [40]. The decreasing inflammatory activity over time, as well as the presence of more diffuse inflammatory processes, which can occur during the transition from the acute to the subacute state and/or in case of underlying autoimmune processes, pose a challenge to classic CMR techniques that require regional signal differences to generate sufficient tissue contrast (for instance, T2weighted imaging as well as early and late gadolinium enhancement (LGE) imaging) [41]. Therefore, more diffuse or low-grade processes may be left undetected by classic CMR techniques. A potential solution to this problem is the normalization against reference tissue, which enables the calculation of a signal intensity ratio. However, this can lead to false negative results in the case of coexisting disease in the reference tissue, such as, for instance, in skeletal muscle for T2-weighted imaging [42,43]. Nonetheless, in recent years, the method's overall ability to visualize diffuse myocardial disease has clearly improved thanks to the advances in parametric mapping techniques [44].

\subsection{CMR Mapping Techniques}

Parametric mapping techniques allow not only the spatial visualization, but also the objective quantification of $\mathrm{T} 1$ and $\mathrm{T} 2$ relaxation times, which are magnetic tissue properties influenced by multiple factors [44]. T1 and T2 relaxation times are displayed as a map (Figure 1), and are calculated on a pixel-by-pixel basis and allow the evaluation of global or regional myocardial T1 and T2 relaxation times. Each deviation from the tissue-specific normal range of these relaxation times (using locally obtained or published values as reference $[45,46])$ indicates a potential change in tissue composition or disease $[44,47,48]$. Importantly, local validation against established norms is necessary for these techniques, as the T1 and T2 relaxation times are dependent on the chosen scan method and CMR scanner. T1 relaxation times can be calculated without so-called native T1 mapping, or after the application of gadolinium-based contrast agents. Based on T1 mapping pre- and post-contrast including adjustment for the current haematocrit value, the extracellular volume can be calculated, which may be useful to detect oedema, hyperaemia, capillary leak, and fibrosis [38,47,49-54].

Overall, CMR mapping techniques show an excellent sensitivity, specificity, and diagnostic accuracy in patients with clinically suspected myocarditis [55,56]. Current evidence indicates that T2 mapping techniques might be more specific for detecting acute inflammation than T1 mapping, and the method also appears to be more sensitive to detecting oedema in the chronic disease state [38]. This is not surprising, as prolongation of $\mathrm{T} 1$ relaxation times is mainly caused by two biological determinates, namely oedema (increase in water due to acute inflammation) and an increase in interstitial space due to fibrosis (later stages of myocardial inflammation or healed state) [44,47]. 

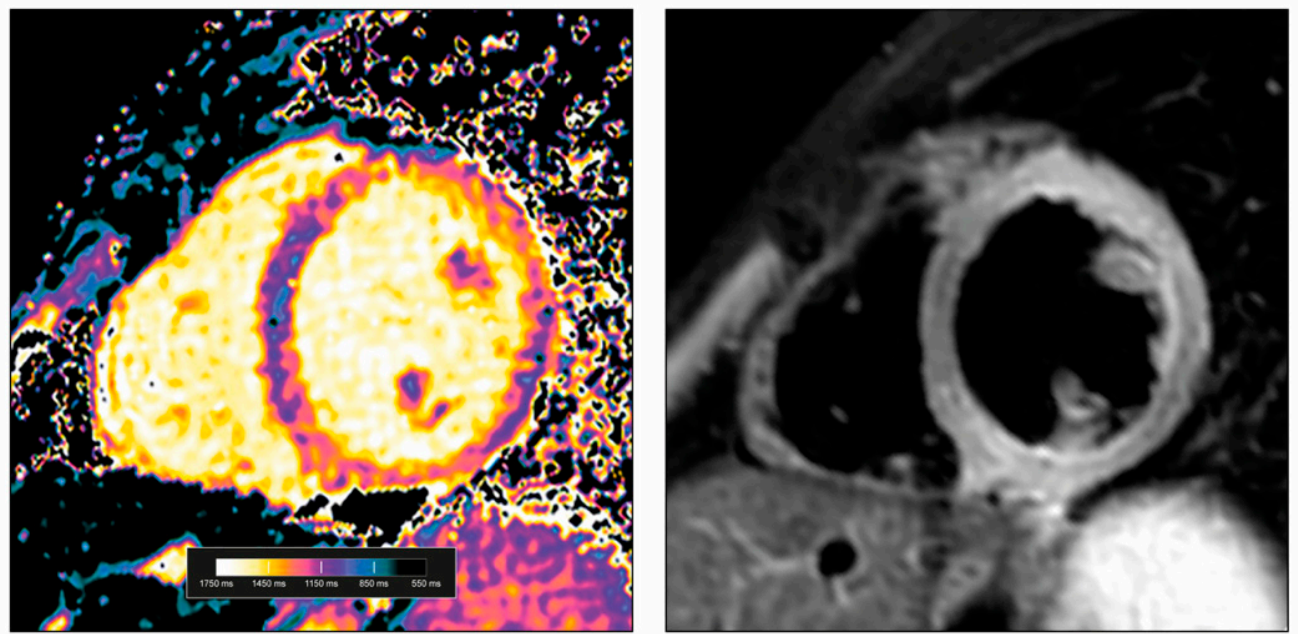

Figure 1. Native T1 map (left) in a patient with acute myocarditis showing prolonged T1 relaxation times in the anterolateral and inferoseptal regions of the left ventricle (1320 $\pm 43 \mathrm{~ms}$ (local reference $999 \pm 31 \mathrm{~ms})$ ). Corresponding T2-weighted black blood short tau inversion recovery sequence (right) with clear signs of oedema in the same regions.

In contrast, prolongation of $\mathrm{T} 2$ relaxations times is solely caused by changes in the tissues water content $[44,57,58]$. However, T1 and T2 mapping techniques seem to have a complementary diagnostic value, which is the reason both methods are recommended to be part of a comprehensive CMR study in patients with clinically suspected myocarditis $[7,44]$. Finally, parametric mapping techniques have the potential to enable the diagnosis and follow-up of patients with myocarditis without using gadolinium-based contrast agents.

\subsection{Myocardial Oedema}

A hallmark of myocardial inflammation is the development of oedema, which is mediated by an array of cytokines. An increased tissue water content (oedema) results in the prolongation of both $\mathrm{T} 1$ and especially $\mathrm{T} 2$ relaxation times (Table 2). These changes can be visualized by several CMR techniques.

Table 2. CMR features in myocarditis according to disease stage and pathologic findings.

\begin{tabular}{|c|c|c|c|c|}
\hline & Oedema & $\begin{array}{c}\text { Hyperaemia/Capillary } \\
\text { Leak }\end{array}$ & Necrosis & $\begin{array}{c}\text { Fibrosis } \\
\text { (Focal/Diffuse) }\end{array}$ \\
\hline $\begin{array}{c}\text { Acute } \\
\text { (active) }\end{array}$ & $\begin{array}{c}\mathrm{T} 2 \uparrow \\
(T 2 \text { SIR/T2 map) } \\
\mathrm{T} 1 \uparrow \\
\text { (native } T 1 / E C V \text { ) }\end{array}$ & $\begin{array}{c}\mathrm{T} 1 \uparrow \\
\text { (native T1/ECV) } \\
\text { EGE - or + }\end{array}$ & LGE - or + & - \\
\hline Chronic & $\begin{array}{c}\mathrm{T} 2 \text { - or } \uparrow \\
\text { (T2 SIR/T2 map) } \\
\text { T1 - or } \uparrow \\
\text { (native T1/ECV) }\end{array}$ & $\begin{array}{c}\mathrm{T} 1-\text { or } \uparrow \\
\text { (native T1/ECV) } \\
\text { EGE - or + }\end{array}$ & LGE - or + & $\begin{array}{c}\text { LGE - or }+ \\
\text { T1 - or } \uparrow \\
\text { (native } T 1 / E C V \text { ) }\end{array}$ \\
\hline Healed & - & - & - & $\begin{array}{c}\text { LGE - or }+ \\
\text { T1 - or } \uparrow \\
\text { (native } T 1 / E C V \text { ) }\end{array}$ \\
\hline
\end{tabular}

Native T1 and ECV reflect not only acute inflammation with oedema, but also the later stages with focal or diffuse fibrosis. ECV, extracellular volume; EGE, early gadolinium enhancement; LGE, late gadolinium enhancement; T2 SIR, T2 signal intensity ratio; $\uparrow$, increased; -, absent/normal; +, present.

Classic T2-weighted imaging, usually using a black-blood short-tau inversion recovery sequence, can visualize myocardial oedema in myocarditis (Figure 1) [49,52-54,59-69]. However, the usefulness of the method is often hampered by its low signal-to-noise ratio, susceptibility to arrhythmias and motion, as well as inconsistent image quality [70,71]. 
According to Lagan et al. [55], the pooled weighted sensitivity, specificity, and diagnostic accuracy of T2-weigthed imaging in myocarditis (based on a qualitative and/or semiquantitative evaluation) is 62,76 , and $67 \%$, respectively. If image analysis is solely based on the calculation of the T2 signal intensity ratio ( $\geq 2.0$ is considered as pathologic), the sensitivity and specificity of the method increase to 68 and 91\%, respectively [56]. When calculating this ratio, it is advisable to use the serratus anterior muscle as a reference tissue, if accessible [72].

T2 mapping techniques, using gradient or spin-echo sequences with multi-echo readouts, are superior in their ability to detect myocardial oedema compared with classic T2weighted imaging $[38,49,52,53,73,74]$. The improved diagnostic performance is attributed to the method's higher signal-to-noise ratio, fewer motion artefacts (secondary to shorter breath-holds), ability to directly calculate T2 relaxation times, and improved inter- and intra-observer variability as well as diagnostic confidence of T2 mapping. Lagan et al. report a pooled sensitivity, specificity, and diagnostic accuracy for T2 mapping in myocarditis of 72,87 , and $79 \%$, respectively [55]. In a further meta-analysis, Kotanidis et al. report a pooled sensitivity and specificity of 78 and $84 \%$, respectively [56]. Furthermore, the method may have the ability to discriminate active from healed myocarditis [52].

Native T1 mapping, using inversion recovery (for instance, the modified Look-Locker inversion recovery (MOLLI) or shortened modified Look-Locker inversion recovery (ShMOLLI)), saturation recovery (saturation recovery single-shot acquisition (SASHA)), or hybrid sequences, is highly useful in patients with clinically suspected myocarditis [38,49,52-54,59,60]. However, native T1 mapping is rather a sensitive marker for myocardial disease in general than for the activity of the disease, as it seems that the method lacks the ability to discriminate acute from chronic disease [52]. Lagan et al. report a pooled sensitivity, specificity, and diagnostic accuracy for T1 mapping in myocarditis of 82, 91, and 86\%, respectively [55]. A further meta-analysis by Kotanidis et al. reports a pooled sensitivity and specificity of 89 and $90 \%$, respectively [56].

Finally, one must bear in mind that myocardial oedema can not only occur in cases of myocardial inflammation, but might also be due to other myocardial diseases such as, for instance, advanced decompensated heart failure with venous congestion [75].

\subsection{Myocardial Hyperaemia and Capillary Leak}

Myocardial inflammation also leads characteristically to hyperaemia, an increased vascular permeability, and an expansion of the interstitial space, which results in a prolongation of the T1 relaxation time as well as an increased uptake and distribution volume for gadolinium-based contrast agents (Table 2). On the one hand, the prolongation of the T1 relaxation time can be visualized and quantified by native T1 mapping [53,59]. On the other hand, the increase in contrast uptake can be depicted by T1-weighted spin echo sequences before and early after the application of gadolinium-based contrast agents. This enables the calculation of the early gadolinium enhancement ratio ( $\geq 4.0$ is considered as pathologic) using skeletal muscle as reference, or the contrast media-induced relative myocardial signal intensity increase ( $\geq 45 \%$ is considered as pathologic) [18]. Although considered useful in patients with clinically suspected myocarditis $[49,53,54,61,63-65,68,69,76]$, it is still unclear whether these methods really visualize hyperaemia or if they just reflect an increase in interstitial space. Lagan et al. report a pooled sensitivity, specificity, and diagnostic accuracy for classic early gadolinium enhancement in myocarditis of 65, 69, and 67\%, respectively [55]. In a further meta-analysis Kotanidis et al. report a pooled sensitivity and specificity of 70 and $74 \%$, respectively [56]. Interestingly, the removal of early gadolinium enhancement from the original Lake Louise Criteria (LLC), which were proposed in 2009 to establish diagnostic CMR criteria for diagnosing patients with clinically suspected myocarditis, does not appear to substantially affect the diagnostic performance $[7,64]$. 


\subsection{Myocardial Necrosis and Fibrosis}

The occurrence of myocyte injury due to severe myocardial inflammation leads to tissue necrosis and eventually to fibrosis and the development of a remaining scar. This results, among others, in the further increase in the distribution volume of gadolinium-based contrast agents, which can be visualized using inversion-recovery prepared gradient echo sequences following a delay after contrast injection (Table 2). The resulting classic LGE images are of great value in patients with clinically suspected myocarditis $[38,49,52-54,59-61,63-68,77-79]$, and show characteristic non-ischemic patterns (a typically patchy appearance with most often subendocardial or mid-wall localization). These LGE patterns are discussed in more detail for each specific myocarditis form in Section 5. LGE is not specific for myocardial inflammation, as it only reflects changes in extracellular space, and cannot reliably differentiate between a more recent or an older episode of myocarditis. Furthermore, the extent of LGE decreases and the signal intensity increases owing to the temporal evolution of myocardial inflammation, as the oedema subsides, and the scar develops [80]. Lagan et al. report a pooled sensitivity, specificity, and diagnostic accuracy for LGE in myocarditis of 63, 85, and 72\%, respectively [55]. A further meta-analysis by Kotanidis et al. reports a pooled sensitivity and specificity of 68 and $96 \%$, respectively [56].

\subsection{Functional and Pericardial Alterations}

Myocardial inflammation can also lead to structural or functional alterations of the heart, such as, for instance, a swollen myocardium, regional wall motion abnormalities, ventricular dilatation, or impairment of diastolic/systolic function. Furthermore, myocardial inflammation can be associated with pericardial involvement, or vice versa. This may result in a pericardial effusion or characteristic CMR findings consistent with pericarditis [81]. Both functional and pericardial alterations are considered as supportive diagnostic criteria $[7,18]$.

Finally, a further strength of CMR in the diagnostic work-up of patients with clinically suspected myocarditis is its ability to exclude other potentially underlying differential diagnoses.

\section{Updated Lake Louise Criteria}

The original LLC [18] have been used extensively in both clinical and research settings $[38,49,53,54,63-65,68]$. In a meta-analysis by Lagan et at., the pooled sensitivity, specificity, and diagnostic accuracy for the original LLC are 77, 81, and 79\%, respectively [55]. A further meta-analysis by Kotanidis et al. reports a pooled sensitivity and specificity of 78 and $88 \%$, respectively [56]. Furthermore, both meta-analyses underline the additional diagnostic potential of parametric mapping techniques as a complement to the classic CMR techniques in the diagnostic work-up of patients with clinically suspected myocarditis.

In 2018, an updated version of the LLC was published [7], which incorporated for the first time CMR mapping techniques into the diagnostic algorithm, as they offer at least theoretically a diagnostic advantage over the original LLC. The updated LLC (Table 3) proposed a "2 out of 2" approach for the diagnosis of myocardial inflammation, which means that one positive T2-based criterion (T2-weigthed imaging or T2 mapping) and one T1-based criterion (T1 mapping, extracellular volume, or LGE) must be fulfilled. Hereby, it should be kept in mind that fulfilling both a positive T2- and T1-based marker increases the specificity of the diagnosis, although the presence of only one positive marker (either T2- or T1-based) makes the diagnosis still likely, albeit with less specificity [7]. 
Table 3. Updated Lake Louise Criteria.

Main criteria ("2 out of 2")

- T2-based imaging

$\bigcirc \quad$ Regional * high T2 signal intensity

or

Global T2 signal intensity ratio $\geq 2.0$ in T2-weighted images

or

Regional or global increase of myocardial T2 relaxation times **

- T1-based imaging

Regional or global increase of native myocardial T1 relaxation times or extracellular or volume $* * *$

Areas with high signal intensity in a non-ischemic distribution pattern in late gadolinium enhancement images

Supportive criteria

- Pericardial inflammation

$\bigcirc \quad$ Pericardial effusion in cine images

or

High signal intensity of the pericardium on late gadolinium enhancement images and/or T1 mapping and/or T2 mapping

- Left ventricular dysfunction

Systolic left ventricular wall motion abnormality in cine images

* Regional refers to an area of at least 10 continuous pixels. ${ }^{* *}$ Published or local normal values. ${ }^{* *}$ T1 mapping is highly sensitive to detecting both acute and chronic forms of increased free water content within the myocardium, and thus is considered as an alternative criterion to early gadolinium enhancement. If paired with late gadolinium enhancement to diagnose myocarditis, the areas of T1 abnormality should be beyond that detected by late gadolinium enhancement. Adapted and modified with permission from Ferreira et al. [7]

\section{CMR in Different Forms of Myocarditis}

The appearance of myocarditis on CMR images is versatile, owing to the broad spectrum of underlying aetiologies (Table 4).

\subsection{Viral Myocarditis}

Viral myocarditis is the most common form in Western countries and has been extensively studied by CMR. It shows a LGE pattern that involves the subepicardial and/or mid-wall layers of the myocardium, predominately in the basal to mid-lateral and inferolateral wall segments of the left ventricle (Figure 2). Frequently, all CMR makers of myocardial inflammation resolve within 5 weeks after the initial presentation [39], but sometimes, sequelae in the form of a scar can remain. CMR has even shown its usefulness in cases of chronic viral myocarditis [82], in which LGE is an important marker that can be found in up to $70 \%$ of patients with biopsy-proven chronic inflammation [83].

\subsection{COVID-19 and Post-Vaccination Associated Myocarditis}

Coronavirus disease 2019 (COVID-19) is caused by the severe acute respiratory syndrome coronavirus 2 (SARS-CoV-2) and leads to various cardiac manifestations, including signs of myocardial injury [84-86]. Numerous cases have been described with clinically suspected myocarditis [87-89]. However, only in a few cases histological evidence of lymphocytic infiltration or the presence of the SARS-CoV-2 genome could be found [90,91]. Based on the current available evidence, viral myocarditis seems to be rare in patients with COVID-19, and the underlying pathomechanism is still somewhat unclear. 
Table 4. Characteristic features of several forms of myocarditis.

\begin{tabular}{|c|c|c|c|c|}
\hline & $\begin{array}{c}\text { Viral } \\
\text { Myocarditis }\end{array}$ & $\begin{array}{c}\text { Cardiac } \\
\text { Sarcoidosis }\end{array}$ & $\begin{array}{c}\text { Giant Cell } \\
\text { Myocarditis }\end{array}$ & $\begin{array}{l}\text { Eosinophilic } \\
\text { Myocarditis }\end{array}$ \\
\hline Demographics & $\begin{array}{l}\text { Mostly young adults, } \\
\text { both genders }\end{array}$ & $\begin{array}{l}\text { Mostly middle-aged, } \\
\text { both genders }\end{array}$ & $\begin{array}{l}\text { Mostly middle-aged, } \\
\text { both genders }\end{array}$ & $\begin{array}{l}\text { Mostly adults } \\
<40 \text { years, } \\
\text { both genders }\end{array}$ \\
\hline $\begin{array}{c}\text { Most common } \\
\text { clinical presentation }\end{array}$ & $\begin{array}{c}\text { Acute coronary } \\
\text { syndrome-like with } \\
\text { eventual infectious } \\
\text { prodrome }\end{array}$ & $\begin{array}{l}\text { Ventricular arrhythmia, } \\
\text { heart block, worsening } \\
\text { heart failure- } \\
\text { Often associated with } \\
\text { extra-cardiac } \\
\text { sarcoidosis }\end{array}$ & $\begin{array}{c}\text { Ventricular arrhythmia, } \\
\text { heart block, worsening } \\
\text { heart failure }\end{array}$ & $\begin{array}{c}\text { Acute coronary } \\
\text { syndrome-like with } \\
\text { fever and dyspnoea }\end{array}$ \\
\hline Clinical course & $\begin{array}{l}\text { Entire spectrum from } \\
\text { asymptomatic to } \\
\text { fulminant course }\end{array}$ & $\begin{array}{l}\text { Entire spectrum from } \\
\text { asymptomatic to } \\
\text { fulminant course }\end{array}$ & $\begin{array}{l}\text { Usually fulminant } \\
\text { course }\end{array}$ & Usually acute \\
\hline $\begin{array}{l}\text { Characteristic } \\
\text { LGE pattern }\end{array}$ & $\begin{array}{l}\text { Subepicardial and/or } \\
\text { mid-wall LGE, } \\
\text { predominantly basal to } \\
\text { mid-lateral and } \\
\text { inferolateral wall } \\
\text { segments }\end{array}$ & $\begin{array}{l}\text { Varying, usually } \\
\text { complex }{ }^{*} \text { LGE } \\
\text { involving both } \\
\text { ventricles including } \\
\text { right ventricular } \\
\text { insertion points }\end{array}$ & $\begin{array}{l}\text { Often extensive, } \\
\text { complex* LGE } \\
\text { involving both } \\
\text { ventricles including } \\
\text { right ventricular } \\
\text { insertion points }\end{array}$ & $\begin{array}{c}\text { Diffuse } \\
\text { subendocardial LGE } \\
\text { with high } \\
\text { signal intensity }\end{array}$ \\
\hline
\end{tabular}

* Can involve all myocardial layers. LGE, late gadolinium enhancement.
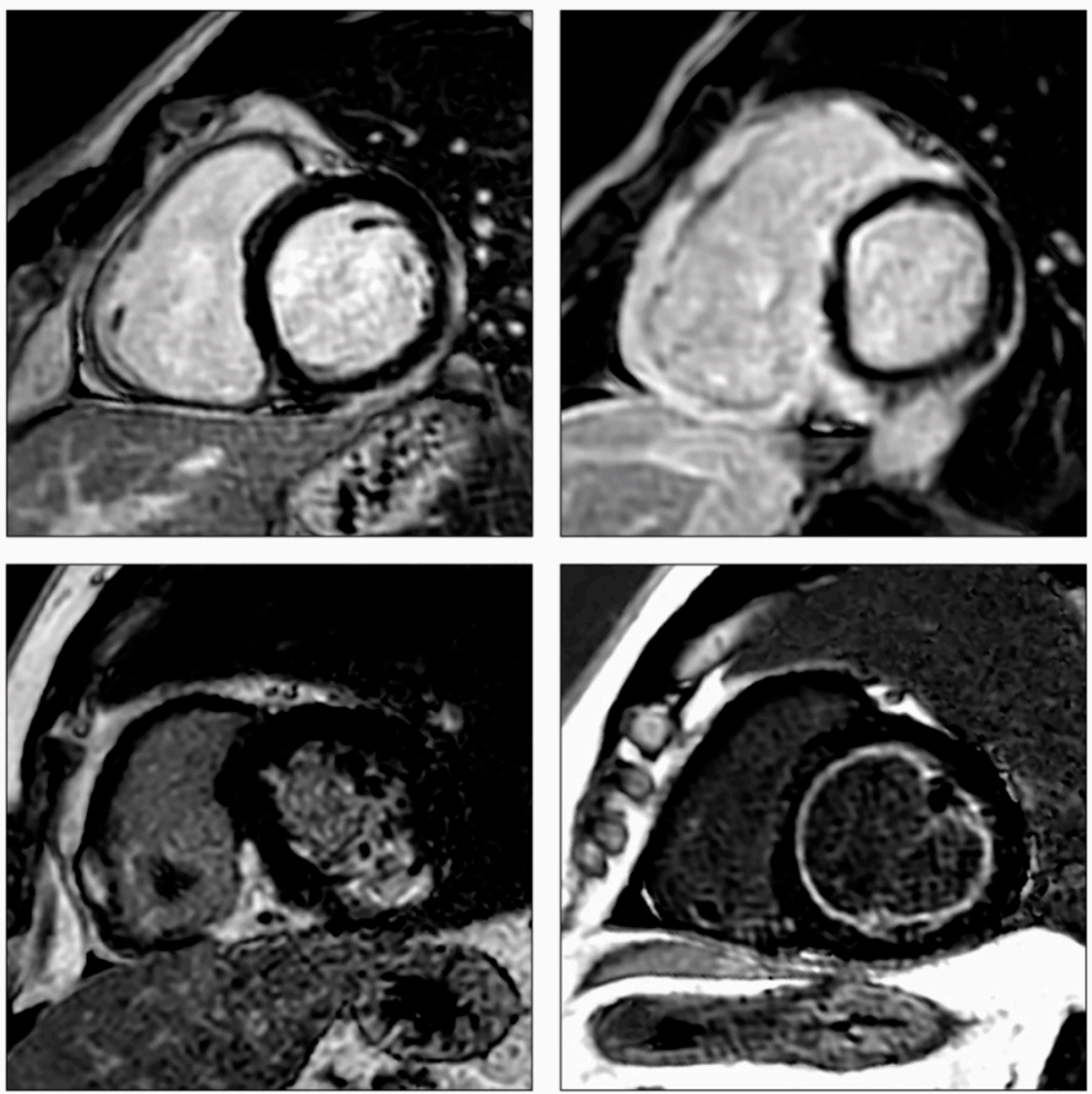

Figure 2. Characteristic late gadolinium enhancement (LGE) patterns in viral myocarditis (upper left, inferolateral subepicardial LGE), giant cell myocarditis (upper right, complex LGE involving both ventricles including the right ventricular insertion points), cardiac sarcoidosis (lower left, complex LGE involving both ventricles including the inferior right ventricular insertion point), and eosinophilic myocarditis (lower right, diffuse subendocardial LGE with high signal intensity). 
Myocarditis following mRNA COVID-19 vaccination is a rare complication in predominately male adolescent and young adults, usually of mild nature [92,93]. In these cases, CMR usually shows classic signs of myocarditis as in viral myocarditis [94]. Still, the long-term outcome of vaccine-related myocarditis remains to be clarified.

\subsection{Giant Cell Myocarditis}

GCM is a rare, often rapidly progressive disease, which usually affects middle-aged adults and carries a high mortality if untreated [95]. The diagnosis of GCM remains challenging and relies mainly on EMB to establish the final diagnosis. CMR often shows signs of extensive inflammation with widespread LGE involving all myocardial layers as well as both ventricles including the right ventricular insertion points (Figure 2) [96-99]. The pattern can look like severe forms of CS [100], which is not surprising as both diseases show a certain clinical and histopathologic overlap. However, the CMR appearance of GCM has so far not been systematically studied.

\subsection{Cardiac Sarcoidosis}

Sarcoidosis is a chronic, multisystem, granulomatous disease of unknown aetiology, which leads in about $5 \%$ of the cases to cardiac involvement with various clinical symptoms [101]. CMR is an established and valuable diagnostic tool in the complicated diagnostic work-up of patients with clinically suspected CS as well as their follow-up [27,102]. The CMR appearance of CS is highly variable depending on the stage of disease and shows varying LGE that can involve all myocardial layers as well as both ventricles including the right ventricular insertion points (Figure 2) [103,104]. Furthermore, it has been shown that CMR has a complementary diagnostic value in combination with Fluorine-18 fluorodeoxyglucose positron emission tomography/computed tomography [28], and adds valuable information concerning prognosis in this challenging patient group $[105,106]$.

\subsection{Eosinophilic Myocarditis}

Eosinophilic myocarditis is characterized by eosinophilic infiltration of the myocardium [107]. It is a rare disease that can be caused by hypersensitivity, allergic reactions, infections, malignancies, vasculitis, and hypereosinophilic syndromes [108]. CMR tends to visualize a diffuse subendocardial LGE pattern with high signal intensity [108,109], which stands in clear contrast to all other forms of myocarditis (Figure 2).

\subsection{Myocarditis in Systemic Immune-Mediated Diseases}

Myocarditis can occur as a complication of systemic immune-mediated diseases such as systemic lupus erythematosus, rheumatoid arthritis, and systemic sclerosis. In these cases, CMR can, with the help of classic as well as novel mapping techniques, detect both subclinical and clinically manifest cardiac involvement [110-113].

\subsection{Immune Checkpoint Inhibitor-Induced Myocarditis}

Immune checkpoint inhibitors are gaining increasing importance in modern cancer treatment. Despite their better safety profile in comparison with chemotherapy, immunerelated adverse events can occur [114]. Immune checkpoint inhibitor-induced myocarditis is such a complication and CMR has shown promising results in this patient group $[115,116]$. However, further studies are needed to systematically characterize the CMR appearance of immune checkpoint inhibitor-induced myocarditis.

\subsection{Myocarditis in Children and Adolescence}

Myocarditis in the paediatric population is rare and remains, as in adults, a difficult diagnosis owing to its heterogenous clinical presentation and broad spectrum of underlying aetiologies. Overall, infectious myocarditis, particularly due to viral infections, is the most frequent form. Using the same diagnostic criteria as in adults, the clinical usefulness of CMR, including parametric mapping techniques, has been demonstrated in the diagnostic 
work-up of paediatric patients with clinically suspected myocarditis [117-121]. However, the overall evidence for CMR imaging in this patient group is still scarce.

\section{Future Directions}

There is an urgent need for more research in the field of myocarditis. Large outcomebased studies are needed to substantiate the usefulness of parametric mapping techniques and the updated LLC in the diagnosis of myocarditis. New imaging markers based on advanced image analysis techniques, such as texture analysis [122,123] and myocardial strain analysis using feature tracking [124], may help to improve the diagnostic and prognostic ability of CMR. Furthermore, hybrid imaging techniques like PET/MR with the potential to also visualize myocardial inflammation on a molecular level might further improve the diagnostic capabilities. One such promising method for molecular inflammation imaging is somatostatin receptor imaging [125-127]. Finally, randomized controlled trials are needed to improve the treatment of patients with inflammatory heart disease.

\section{Conclusions}

CMR is an established and highly valuable clinical tool in the diagnostic work-up of patients with clinically suspected myocarditis. The method's strength lies in its multiparametric tissue characterization ability and the established diagnostic criteria for the detection of myocardial inflammation. Although widely used in clinical practice, the method also faces several limitations, which can hopefully be resolved in the near future.

Author Contributions: C.L.P. performed the main literature search, supported by E.B. (Emanuele Bobbio), C.P. and S.A.G. C.L.P. wrote the initial draft of the manuscript, with all co-authors (E.B. (Emanuele Bobbio), E.B. (Entela Bollano), N.B., C.P., J.H., K.M.L. and S.A.G.) making substantial contributions and critically reviewing its content. All authors have read and agreed to the published version of the manuscript.

Funding: This work received support from the Swedish state under the agreement between the Swedish government and the county councils, the ALF-agreement (ALFGBG-874631).

Acknowledgments: We thank the Departments of Clinical Physiology, Radiology, Medical Physics and Biomedical Engineering, and Cardiology at the Sahlgrenska University Hospital for their invaluable support of our research.

Conflicts of Interest: The authors declare no conflict of interest.

\section{References}

1. Richardson, P.; McKenna, W.; Bristow, M.; Maisch, B.; Mautner, B.; O’Connell, J.; Olsen, E.; Thiene, G.; Goodwin, J.; Gyarfas, I.; et al. Report of the 1995 World Health Organization/International Society and Federation of Cardiology Task Force on the Definition and Classification of cardiomyopathies. Circulation 1996, 93, 841-842. [CrossRef]

2. Caforio, A.L.; Pankuweit, S.; Arbustini, E.; Basso, C.; Gimeno-Blanes, J.; Felix, S.B.; Fu, M.; Helio, T.; Heymans, S.; Jahns, R.; et al. Current state of knowledge on aetiology, diagnosis, management, and therapy of myocarditis: A position statement of the European Society of Cardiology Working Group on Myocardial and Pericardial Diseases. Eur. Heart J. 2013, 34, $2636-2648$. [CrossRef] [PubMed]

3. Kindermann, I.; Barth, C.; Mahfoud, F.; Ukena, C.; Lenski, M.; Yilmaz, A.; Klingel, K.; Kandolf, R.; Sechtem, U.; Cooper, L.T.; et al. Update on myocarditis. J. Am. Coll. Cardiol. 2012, 59, 779-792. [CrossRef] [PubMed]

4. Mahmood, S.S.; Fradley, M.G.; Cohen, J.V.; Nohria, A.; Reynolds, K.L.; Heinzerling, L.M.; Sullivan, R.J.; Damrongwatanasuk, R.; Chen, C.L.; Gupta, D.; et al. Myocarditis in Patients Treated with Immune Checkpoint Inhibitors. J. Am. Coll. Cardiol. 2018, 71, 1755-1764. [CrossRef] [PubMed]

5. D’Ambrosio, A.; Patti, G.; Manzoli, A.; Sinagra, G.; Di Lenarda, A.; Silvestri, F.; Di Sciascio, G. The fate of acute myocarditis between spontaneous improvement and evolution to dilated cardiomyopathy: A review. Heart 2001, 85, 499-504. [CrossRef]

6. Fabre, A.; Sheppard, M.N. Sudden adult death syndrome and other non-ischaemic causes of sudden cardiac death. Heart 2006, 92, 316-320. [CrossRef]

7. Ferreira, V.M.; Schulz-Menger, J.; Holmvang, G.; Kramer, C.M.; Carbone, I.; Sechtem, U.; Kindermann, I.; Gutberlet, M.; Cooper, L.T.; Liu, P.; et al. Cardiovascular Magnetic Resonance in Nonischemic Myocardial Inflammation: Expert Recommendations. J. Am. Coll. Cardiol. 2018, 72, 3158-3176. [CrossRef] 
8. Heymans, S.; Eriksson, U.; Lehtonen, J.; Cooper, L.T., Jr. The Quest for New Approaches in Myocarditis and Inflammatory Cardiomyopathy. J. Am. Coll. Cardiol. 2016, 68, 2348-2364. [CrossRef]

9. Biesbroek, P.S.; Hirsch, A.; Zweerink, A.; van de Ven, P.M.; Beek, A.M.; Groenink, M.; Windhausen, F.; Planken, R.N.; van Rossum, A.C.; Nijveldt, R. Additional diagnostic value of CMR to the European Society of Cardiology (ESC) position statement criteria in a large clinical population of patients with suspected myocarditis. Eur. Heart J. Cardiovasc. Imaging 2018, 19, 1397-1407. [CrossRef]

10. Aquaro, G.D.; Perfetti, M.; Camastra, G.; Monti, L.; Dellegrottaglie, S.; Moro, C.; Pepe, A.; Todiere, G.; Lanzillo, C.; Scatteia, A.; et al. Cardiac MR with Late Gadolinium Enhancement in Acute Myocarditis with Preserved Systolic Function: ITAMY Study. J. Am. Coll. Cardiol. 2017, 70, 1977-1987. [CrossRef]

11. Grani, C.; Eichhorn, C.; Biere, L.; Murthy, V.L.; Agarwal, V.; Kaneko, K.; Cuddy, S.; Aghayev, A.; Steigner, M.; Blankstein, R.; et al. Prognostic Value of Cardiac Magnetic Resonance Tissue Characterization in Risk Stratifying Patients with Suspected Myocarditis J. Am. Coll. Cardiol. 2017, 70, 1964-1976. [CrossRef] [PubMed]

12. McDonagh, T.A.; Metra, M.; Adamo, M.; Gardner, R.S.; Baumbach, A.; Bohm, M.; Burri, H.; Butler, J.; Celutkiene, J.; Chioncel, O.; et al. 2021 ESC Guidelines for the diagnosis and treatment of acute and chronic heart failure. Eur. Heart J. 2021, 42, 3599-3726. [CrossRef]

13. Bozkurt, B.; Colvin, M.; Cook, J.; Cooper, L.T.; Deswal, A.; Fonarow, G.C.; Francis, G.S.; Lenihan, D.; Lewis, E.F.; McNamara, D.M.; et al. Current Diagnostic and Treatment Strategies for Specific Dilated Cardiomyopathies: A Scientific Statement from the American Heart Association. Circulation 2016, 134, e579-e646. [CrossRef] [PubMed]

14. Liu, P.; Martino, T.; Opavsky, M.A.; Penninger, J. Viral myocarditis: Balance between viral infection and immune response. Can. J. Cardiol. 1996, 12, 935-943. [PubMed]

15. Cooper, L.T., Jr. Myocarditis. N. Engl. J. Med. 2009, 360, 1526-1538. [CrossRef] [PubMed]

16. Ukena, C.; Mahfoud, F.; Kindermann, I.; Kandolf, R.; Kindermann, M.; Bohm, M. Prognostic electrocardiographic parameters in patients with suspected myocarditis. Eur. J. Heart Fail. 2011, 13, 398-405. [CrossRef]

17. Fung, G.; Luo, H.; Qiu, Y.; Yang, D.; McManus, B. Myocarditis. Circ. Res. 2016, 118, 496-514. [CrossRef]

18. Friedrich, M.G.; Sechtem, U.; Schulz-Menger, J.; Holmvang, G.; Alakija, P.; Cooper, L.T.; White, J.A.; Abdel-Aty, H.; Gutberlet, M.; Prasad, S.; et al. Cardiovascular magnetic resonance in myocarditis: A JACC White Paper. J. Am. Coll. Cardiol. 2009, 53, 1475-1487. [CrossRef]

19. Morgera, T.; Di Lenarda, A.; Dreas, L.; Pinamonti, B.; Humar, F.; Bussani, R.; Silvestri, F.; Chersevani, D.; Camerini, F. Electrocardiography of myocarditis revisited: Clinical and prognostic significance of electrocardiographic changes. Am. Heart J. 1992, 124, 455-467. [CrossRef]

20. Lauer, B.; Niederau, C.; Kuhl, U.; Schannwell, M.; Pauschinger, M.; Strauer, B.E.; Schultheiss, H.P. Cardiac troponin T in patients with clinically suspected myocarditis. J. Am. Coll. Cardiol. 1997, 30, 1354-1359. [CrossRef]

21. Ukena, C.; Kindermann, M.; Mahfoud, F.; Geisel, J.; Lepper, P.M.; Kandolf, R.; Bohm, M.; Kindermann, I. Diagnostic and prognostic validity of different biomarkers in patients with suspected myocarditis. Clin. Res. Cardiol. 2014, 103, 743-751. [CrossRef] [PubMed]

22. Mahfoud, F.; Gartner, B.; Kindermann, M.; Ukena, C.; Gadomski, K.; Klingel, K.; Kandolf, R.; Bohm, M.; Kindermann, I. Virus serology in patients with suspected myocarditis: Utility or futility? Eur. Heart J. 2011, 32, 897-903. [CrossRef] [PubMed]

23. Jeserich, M.; Konstantinides, S.; Pavlik, G.; Bode, C.; Geibel, A. Non-invasive imaging in the diagnosis of acute viral myocarditis. Clin. Res. Cardiol. 2009, 98, 753-763. [CrossRef] [PubMed]

24. Logstrup, B.B.; Nielsen, J.M.; Kim, W.Y.; Poulsen, S.H. Myocardial oedema in acute myocarditis detected by echocardiographic 2D myocardial deformation analysis. Eur. Heart J. Cardiovasc. Imaging 2016, 17, 1018-1026. [CrossRef] [PubMed]

25. Leitman, M.; Vered, Z.; Tyomkin, V.; Macogon, B.; Moravsky, G.; Peleg, E.; Copel, L. Speckle tracking imaging in inflammatory heart diseases. Int. J. Cardiovasc. Imaging 2018, 34, 787-792. [CrossRef]

26. Uppu, S.C.; Shah, A.; Weigand, J.; Nielsen, J.C.; Ko, H.H.; Parness, I.A.; Srivastava, S. Two-dimensional speckle-tracking-derived segmental peak systolic longitudinal strain identifies regional myocardial involvement in patients with myocarditis and normal global left ventricular systolic function. Pediatr. Cardiol. 2015, 36, 950-959. [CrossRef]

27. Birnie, D.H.; Sauer, W.H.; Bogun, F.; Cooper, J.M.; Culver, D.A.; Duvernoy, C.S.; Judson, M.A.; Kron, J.; Mehta, D.; Cosedis Nielsen, J.; et al. HRS expert consensus statement on the diagnosis and management of arrhythmias associated with cardiac sarcoidosis. Heart Rhythm 2014, 11, 1305-1323. [CrossRef]

28. Vita, T.; Okada, D.R.; Veillet-Chowdhury, M.; Bravo, P.E.; Mullins, E.; Hulten, E.; Agrawal, M.; Madan, R.; Taqueti, V.R.; Steigner, M.; et al. Complementary Value of Cardiac Magnetic Resonance Imaging and Positron Emission Tomography/Computed Tomography in the Assessment of Cardiac Sarcoidosis. Circ. Cardiovasc. Imaging 2018, 11, e007030. [CrossRef]

29. Kruse, M.J.; Kovell, L.; Kasper, E.K.; Pomper, M.G.; Moller, D.R.; Solnes, L.; Chen, E.S.; Schindler, T.H. Myocardial Blood Flow and Inflammatory Cardiac Sarcoidosis. JACC Cardiovasc. Imaging 2017, 10, 157-167. [CrossRef]

30. Kadkhodayan, A.; Chareonthaitawee, P.; Raman, S.V.; Cooper, L.T. Imaging of Inflammation in Unexplained Cardiomyopathy. JACC Cardiovasc. Imaging 2016, 9, 603-617. [CrossRef]

31. Polte, C.L.; Burck, I.; Gjertsson, P.; Lomsky, M.; Nekolla, S.G.; Nagel, E. Cardiac Positron Emission Tomography: A Clinical Perspective. Curr. Cardiovasc. Imaging Rep. 2016, 9, 9. [CrossRef] 
32. Aretz, H.T.; Billingham, M.E.; Edwards, W.D.; Factor, S.M.; Fallon, J.T.; Fenoglio, J.J., Jr.; Olsen, E.G.; Schoen, F.J. Myocarditis. A histopathologic definition and classification. Am. J. Cardiovasc. Pathol. 1987, 1, 3-14. [PubMed]

33. Cooper, L.T.; Baughman, K.L.; Feldman, A.M.; Frustaci, A.; Jessup, M.; Kuhl, U.; Levine, G.N.; Narula, J.; Starling, R.C.; Towbin, J.; et al. The role of endomyocardial biopsy in the management of cardiovascular disease: A scientific statement from the American Heart Association, the American College of Cardiology, and the European Society of Cardiology. Circulation 2007, 116, 2216-2233. [CrossRef]

34. Yilmaz, A.; Kindermann, I.; Kindermann, M.; Mahfoud, F.; Ukena, C.; Athanasiadis, A.; Hill, S.; Mahrholdt, H.; Voehringer, M.; Schieber, M.; et al. Comparative evaluation of left and right ventricular endomyocardial biopsy: Differences in complication rate and diagnostic performance. Circulation 2010, 122, 900-909. [CrossRef] [PubMed]

35. Kandolin, R.; Lehtonen, J.; Salmenkivi, K.; Raisanen-Sokolowski, A.; Lommi, J.; Kupari, M. Diagnosis, treatment, and outcome of giant-cell myocarditis in the era of combined immunosuppression. Circ. Heart Fail. 2013, 6, 15-22. [CrossRef] [PubMed]

36. Shields, R.C.; Tazelaar, H.D.; Berry, G.J.; Cooper, L.T., Jr. The role of right ventricular endomyocardial biopsy for idiopathic giant cell myocarditis. J. Card. Fail. 2002, 8, 74-78. [CrossRef]

37. Friedrich, M.G.; Marcotte, F. Cardiac magnetic resonance assessment of myocarditis. Circ. Cardiovasc. Imaging 2013, 6, 833-839. [CrossRef]

38. Lurz, P.; Luecke, C.; Eitel, I.; Fohrenbach, F.; Frank, C.; Grothoff, M.; de Waha, S.; Rommel, K.P.; Lurz, J.A.; Klingel, K.; et al Comprehensive Cardiac Magnetic Resonance Imaging in Patients with Suspected Myocarditis: The MyoRacer-Trial. J. Am. Coll. Cardiol. 2016, 67, 1800-1811. [CrossRef]

39. Luetkens, J.A.; Homsi, R.; Dabir, D.; Kuetting, D.L.; Marx, C.; Doerner, J.; Schlesinger-Irsch, U.; Andrie, R.; Sprinkart, A.M.; Schmeel, F.C.; et al. Comprehensive Cardiac Magnetic Resonance for Short-Term Follow-Up in Acute Myocarditis. J. Am. Heart Assoc. 2016, 5, e003603. [CrossRef]

40. Francone, M.; Chimenti, C.; Galea, N.; Scopelliti, F.; Verardo, R.; Galea, R.; Carbone, I.; Catalano, C.; Fedele, F.; Frustaci, A. CMR sensitivity varies with clinical presentation and extent of cell necrosis in biopsy-proven acute myocarditis. JACC Cardiovasc. Imaging 2014, 7, 254-263. [CrossRef]

41. Nagel, E.; Kwong, R.Y.; Chandrashekhar, Y.S. CMR in Nonischemic Myocardial Inflammation: Solving the Problem of Diagnosing Myocarditis or Still Diagnostic Ambiguity? JACC Cardiovasc. Imaging 2020, 13, 163-166. [CrossRef]

42. Laissy, J.P.; Hyafil, F.; Feldman, L.J.; Juliard, J.M.; Schouman-Claeys, E.; Steg, P.G.; Faraggi, M. Differentiating acute myocardial infarction from myocarditis: Diagnostic value of early- and delayed-perfusion cardiac MR imaging. Radiology 2005, 237, 75-82. [CrossRef] [PubMed]

43. Ferreira, V.M.; Piechnik, S.K.; Dall'Armellina, E.; Karamitsos, T.D.; Francis, J.M.; Ntusi, N.; Holloway, C.; Choudhury, R.P.; Kardos, A.; Robson, M.D.; et al. T(1) mapping for the diagnosis of acute myocarditis using CMR: Comparison to T2-weighted and late gadolinium enhanced imaging. JACC Cardiovasc. Imaging 2013, 6, 1048-1058. [CrossRef] [PubMed]

44. Messroghli, D.R.; Moon, J.C.; Ferreira, V.M.; Grosse-Wortmann, L.; He, T.; Kellman, P.; Mascherbauer, J.; Nezafat, R.; Salerno, M.; Schelbert, E.B.; et al. Clinical recommendations for cardiovascular magnetic resonance mapping of T1, T2, T2* and extracellular volume: A consensus statement by the Society for Cardiovascular Magnetic Resonance (SCMR) endorsed by the European Association for Cardiovascular Imaging (EACVI). J. Cardiovasc. Magn. Reson. 2017, 19, 75. [CrossRef] [PubMed]

45. Dabir, D.; Child, N.; Kalra, A.; Rogers, T.; Gebker, R.; Jabbour, A.; Plein, S.; Yu, C.Y.; Otton, J.; Kidambi, A.; et al. Reference values for healthy human myocardium using a T1 mapping methodology: Results from the International T1 Multicenter cardiovascular magnetic resonance study. J. Cardiovasc. Magn. Reson. 2014, 16, 69. [CrossRef]

46. Baessler, B.; Schaarschmidt, F.; Stehning, C.; Schnackenburg, B.; Maintz, D.; Bunck, A.C. A systematic evaluation of three different cardiac T2-mapping sequences at 1.5 and 3T in healthy volunteers. Eur. J. Radiol. 2015, 84, 2161-2170. [CrossRef]

47. Haaf, P.; Garg, P.; Messroghli, D.R.; Broadbent, D.A.; Greenwood, J.P.; Plein, S. Cardiac T1 Mapping and Extracellular Volume (ECV) in clinical practice: A comprehensive review. J. Cardiovasc. Magn. Reson. 2016, 18, 89. [CrossRef]

48. Moon, J.C.; Messroghli, D.R.; Kellman, P.; Piechnik, S.K.; Robson, M.D.; Ugander, M.; Gatehouse, P.D.; Arai, A.E.; Friedrich, M.G.; Neubauer, S.; et al. Myocardial T1 mapping and extracellular volume quantification: A Society for Cardiovascular Magnetic Resonance (SCMR) and CMR Working Group of the European Society of Cardiology consensus statement. J. Cardiovasc. Magn. Reson. 2013, 15, 92. [CrossRef]

49. Radunski, U.K.; Lund, G.K.; Stehning, C.; Schnackenburg, B.; Bohnen, S.; Adam, G.; Blankenberg, S.; Muellerleile, K. CMR in patients with severe myocarditis: Diagnostic value of quantitative tissue markers including extracellular volume imaging. JACC Cardiovasc. Imaging 2014, 7, 667-675. [CrossRef]

50. Radunski, U.K.; Lund, G.K.; Saring, D.; Bohnen, S.; Stehning, C.; Schnackenburg, B.; Avanesov, M.; Tahir, E.; Adam, G.; Blankenberg, S.; et al. T1 and T2 mapping cardiovascular magnetic resonance imaging techniques reveal unapparent myocardial injury in patients with myocarditis. Clin. Res. Cardiol. 2017, 106, 10-17. [CrossRef]

51. Nadjiri, J.; Nieberler, H.; Hendrich, E.; Greiser, A.; Will, A.; Martinoff, S.; Hadamitzky, M. Performance of native and contrastenhanced T1 mapping to detect myocardial damage in patients with suspected myocarditis: A head-to-head comparison of different cardiovascular magnetic resonance techniques. Int. J. Cardiovasc. Imaging 2017, 33, 539-547. [CrossRef] [PubMed]

52. Von Knobelsdorff-Brenkenhoff, F.; Schuler, J.; Doganguzel, S.; Dieringer, M.A.; Rudolph, A.; Greiser, A.; Kellman, P.; Schulz-Menger, J. Detection and Monitoring of Acute Myocarditis Applying Quantitative Cardiovascular Magnetic Resonance. Circ. Cardiovasc. Imaging 2017, 10, e005242. [CrossRef] [PubMed] 
53. Luetkens, J.A.; Homsi, R.; Sprinkart, A.M.; Doerner, J.; Dabir, D.; Kuetting, D.L.; Block, W.; Andrie, R.; Stehning, C.; Fimmers, R.; et al. Incremental value of quantitative CMR including parametric mapping for the diagnosis of acute myocarditis. Eur. Heart J. Cardiovasc. Imaging 2016, 17, 154-161. [CrossRef] [PubMed]

54. Luetkens, J.A.; Doerner, J.; Thomas, D.K.; Dabir, D.; Gieseke, J.; Sprinkart, A.M.; Fimmers, R.; Stehning, C.; Homsi, R.; Schwab, J.O.; et al. Acute myocarditis: Multiparametric cardiac MR imaging. Radiology 2014, 273, 383-392. [CrossRef]

55. Lagan, J.; Schmitt, M.; Miller, C.A. Clinical applications of multi-parametric CMR in myocarditis and systemic inflammatory diseases. Int. J. Cardiovasc. Imaging 2018, 34, 35-54. [CrossRef]

56. Kotanidis, C.P.; Bazmpani, M.A.; Haidich, A.B.; Karvounis, C.; Antoniades, C.; Karamitsos, T.D. Diagnostic Accuracy of Cardiovascular Magnetic Resonance in Acute Myocarditis: A Systematic Review and Meta-Analysis. JACC Cardiovasc. Imaging 2018, 11, 1583-1590. [CrossRef]

57. Verhaert, D.; Thavendiranathan, P.; Giri, S.; Mihai, G.; Rajagopalan, S.; Simonetti, O.P.; Raman, S.V. Direct T2 quantification of myocardial edema in acute ischemic injury. JACC Cardiovasc. Imaging 2011, 4, 269-278. [CrossRef]

58. Abdel-Aty, H.; Simonetti, O.; Friedrich, M.G. T2-weighted cardiovascular magnetic resonance imaging. J. Magn. Reson. Imaging 2007, 26, 452-459. [CrossRef]

59. Ferreira, V.M.; Piechnik, S.K.; Dall'Armellina, E.; Karamitsos, T.D.; Francis, J.M.; Ntusi, N.; Holloway, C.; Choudhury, R.P.; Kardos, A.; Robson, M.D.; et al. Native T1-mapping detects the location, extent and patterns of acute myocarditis without the need for gadolinium contrast agents. J. Cardiovasc. Magn. Reson. 2014, 16, 36. [CrossRef]

60. Hinojar, R.; Foote, L.; Arroyo Ucar, E.; Jackson, T.; Jabbour, A.; Yu, C.Y.; McCrohon, J.; Higgins, D.M.; Carr-White, G.; Mayr, M.; et al. Native T1 in discrimination of acute and convalescent stages in patients with clinical diagnosis of myocarditis: A proposed diagnostic algorithm using CMR. JACC Cardiovasc. Imaging 2015, 8, 37-46. [CrossRef]

61. Rottgen, R.; Christiani, R.; Freyhardt, P.; Gutberlet, M.; Schultheiss, H.P.; Hamm, B.; Kuhl, U. Magnetic resonance imaging findings in acute myocarditis and correlation with immunohistological parameters. Eur. Radiol. 2011, 21, 1259-1266. [CrossRef] [PubMed]

62. Potet, J.; Rahmouni, A.; Mayer, J.; Vignaud, A.; Lim, P.; Luciani, A.; Dubois-Rande, J.L.; Kobeiter, H.; Deux, J.F. Detection of myocardial edema with low-b-value diffusion-weighted echo-planar imaging sequence in patients with acute myocarditis. Radiology 2013, 269, 362-369. [CrossRef] [PubMed]

63. Abdel-Aty, H.; Boye, P.; Zagrosek, A.; Wassmuth, R.; Kumar, A.; Messroghli, D.; Bock, P.; Dietz, R.; Friedrich, M.G.; Schulz-Menger, J. Diagnostic performance of cardiovascular magnetic resonance in patients with suspected acute myocarditis: Comparison of different approaches. J. Am. Coll. Cardiol. 2005, 45, 1815-1822. [CrossRef] [PubMed]

64. Chu, G.C.; Flewitt, J.A.; Mikami, Y.; Vermes, E.; Friedrich, M.G. Assessment of acute myocarditis by cardiovascular MR: Diagnostic performance of shortened protocols. Int. J. Cardiovasc. Imaging 2013, 29, 1077-1083. [CrossRef] [PubMed]

65. Lurz, P.; Eitel, I.; Adam, J.; Steiner, J.; Grothoff, M.; Desch, S.; Fuernau, G.; de Waha, S.; Sareban, M.; Luecke, C.; et al. Diagnostic performance of CMR imaging compared with EMB in patients with suspected myocarditis. JACC Cardiovasc. Imaging 2012, 5, 513-524. [CrossRef] [PubMed]

66. Rieker, O.; Mohrs, O.; Oberholzer, K.; Kreitner, K.F.; Thelen, M. Cardiac MRI in suspected myocarditis. Rofo 2002, 174, 1530-1536. [CrossRef]

67. Jeserich, M.; Konstantinides, S.; Olschewski, M.; Pavlik, G.; Bode, C.; Geibel, A. Diagnosis of early myocarditis after respiratory or gastrointestinal tract viral infection: Insights from cardiovascular magnetic resonance. Clin. Res. Cardiol. 2010, 99, 707-714. [CrossRef]

68. Schwab, J.; Rogg, H.J.; Pauschinger, M.; Fessele, K.; Bareiter, T.; Bar, I.; Loose, R. Functional and Morphological Parameters with Tissue Characterization of Cardiovascular Magnetic Imaging in Clinically Verified “Infarct-like Myocarditis". Rofo 2016, 188, 365-373. [CrossRef]

69. Laissy, J.P.; Messin, B.; Varenne, O.; Iung, B.; Karila-Cohen, D.; Schouman-Claeys, E.; Steg, P.G. MRI of acute myocarditis: A comprehensive approach based on various imaging sequences. Chest 2002, 122, 1638-1648. [CrossRef]

70. Nordlund, D.; Klug, G.; Heiberg, E.; Koul, S.; Larsen, T.H.; Hoffmann, P.; Metzler, B.; Erlinge, D.; Atar, D.; Aletras, A.H.; et al Multi-vendor, multicentre comparison of contrast-enhanced SSFP and T2-STIR CMR for determining myocardium at risk in ST-elevation myocardial infarction. Eur. Heart J. Cardiovasc. Imaging 2016, 17, 744-753. [CrossRef]

71. Kellman, P.; Aletras, A.H.; Mancini, C.; McVeigh, E.R.; Arai, A.E. T2-prepared SSFP improves diagnostic confidence in edema imaging in acute myocardial infarction compared to turbo spin echo. Magn. Reson. Med. 2007, 57, 891-897. [CrossRef] [PubMed]

72. Carbone, I.; Childs, H.; Aljizeeri, A.; Merchant, N.; Friedrich, M.G. Importance of Reference Muscle Selection in Quantitative Signal Intensity Analysis of T2-Weighted Images of Myocardial Edema Using a T2 Ratio Method. Biomed. Res. Int. 2015, 2015, 232649. [CrossRef] [PubMed]

73. Baessler, B.; Schaarschmidt, F.; Dick, A.; Stehning, C.; Schnackenburg, B.; Michels, G.; Maintz, D.; Bunck, A.C. Mapping tissue inhomogeneity in acute myocarditis: A novel analytical approach to quantitative myocardial edema imaging by T2-mapping. $J$. Cardiovasc. Magn. Reson. 2015, 17, 115. [CrossRef] [PubMed]

74. Bohnen, S.; Radunski, U.K.; Lund, G.K.; Kandolf, R.; Stehning, C.; Schnackenburg, B.; Adam, G.; Blankenberg, S.; Muellerleile, K Performance of $\mathrm{t} 1$ and $\mathrm{t} 2$ mapping cardiovascular magnetic resonance to detect active myocarditis in patients with recent-onset heart failure. Circ. Cardiovasc. Imaging 2015, 8, e003073. [CrossRef] 
75. Verbrugge, F.H.; Bertrand, P.B.; Willems, E.; Gielen, E.; Mullens, W.; Giri, S.; Tang, W.H.W.; Raman, S.V.; Verhaert, D. Global myocardial oedema in advanced decompensated heart failure. Eur. Heart J. Cardiovasc. Imaging 2017, 18, 787-794. [CrossRef]

76. Friedrich, M.G.; Strohm, O.; Schulz-Menger, J.; Marciniak, H.; Luft, F.C.; Dietz, R. Contrast media-enhanced magnetic resonance imaging visualizes myocardial changes in the course of viral myocarditis. Circulation 1998, 97, 1802-1809. [CrossRef]

77. Jeserich, M.; Merkely, B.; Schlosser, P.; Kimmel, S.; Pavlik, G.; Achenbach, S. Assessment of edema using STIR+ via 3D cardiovascular magnetic resonance imaging in patients with suspected myocarditis. Magn. Reson. Mater. Phys. Biol. Med. 2017, 30, 309-316. [CrossRef]

78. Yilmaz, A.; Mahrholdt, H.; Athanasiadis, A.; Vogelsberg, H.; Meinhardt, G.; Voehringer, M.; Kispert, E.M.; Deluigi, C.; Baccouche, H.; Spodarev, E.; et al. Coronary vasospasm as the underlying cause for chest pain in patients with PVB19 myocarditis. Heart 2008, 94, 1456-1463. [CrossRef]

79. Mahrholdt, H.; Wagner, A.; Deluigi, C.C.; Kispert, E.; Hager, S.; Meinhardt, G.; Vogelsberg, H.; Fritz, P.; Dippon, J.; Bock, C.T.; et al. Presentation, patterns of myocardial damage, and clinical course of viral myocarditis. Circulation 2006, 114, 1581-1590. [CrossRef]

80. Ammirati, E.; Moroni, F.; Sormani, P.; Peritore, A.; Milazzo, A.; Quattrocchi, G.; Cipriani, M.; Oliva, F.; Giannattasio, C.; Frigerio, M.; et al. Quantitative changes in late gadolinium enhancement at cardiac magnetic resonance in the early phase of acute myocarditis. Int. J. Cardiol. 2017, 231, 216-221. [CrossRef]

81. Bogaert, J.; Francone, M. Cardiovascular magnetic resonance in pericardial diseases. J. Cardiovasc. Magn. Reson. 2009, 11, 14. [CrossRef]

82. Gutberlet, M.; Spors, B.; Thoma, T.; Bertram, H.; Denecke, T.; Felix, R.; Noutsias, M.; Schultheiss, H.P.; Kuhl, U. Suspected chronic myocarditis at cardiac MR: Diagnostic accuracy and association with immunohistologically detected inflammation and viral persistence. Radiology 2008, 246, 401-409. [CrossRef] [PubMed]

83. De Cobelli, F.; Pieroni, M.; Esposito, A.; Chimenti, C.; Belloni, E.; Mellone, R.; Canu, T.; Perseghin, G.; Gaudio, C.; Maseri, A.; et al. Delayed gadolinium-enhanced cardiac magnetic resonance in patients with chronic myocarditis presenting with heart failure or recurrent arrhythmias. J. Am. Coll. Cardiol. 2006, 47, 1649-1654. [CrossRef] [PubMed]

84. Satterfield, B.A.; Bhatt, D.L.; Gersh, B.J. Cardiac involvement in the long-term implications of COVID-19. Nat. Rev. Cardiol. 2021. [CrossRef] [PubMed]

85. Huang, L.; Zhao, P.; Tang, D.; Zhu, T.; Han, R.; Zhan, C.; Liu, W.; Zeng, H.; Tao, Q.; Xia, L. Cardiac Involvement in Patients Recovered from COVID-2019 Identified Using Magnetic Resonance Imaging. JACC Cardiovasc. Imaging 2020, 13, $2330-2339$. [CrossRef]

86. Pan, C.; Zhang, Z.; Luo, L.; Wu, W.; Jia, T.; Lu, L.; Liu, W.V.; Qin, Y.; Hu, F.; Ding, X.; et al. Cardiac T1 and T2 Mapping Showed Myocardial Involvement in Recovered COVID-19 Patients Initially Considered Devoid of Cardiac Damage. J. Magn. Reson. Imaging 2021, 54, 421-428. [CrossRef]

87. Inciardi, R.M.; Lupi, L.; Zaccone, G.; Italia, L.; Raffo, M.; Tomasoni, D.; Cani, D.S.; Cerini, M.; Farina, D.; Gavazzi, E.; et al. Cardiac Involvement in a Patient with Coronavirus Disease 2019 (COVID-19). JAMA Cardiol. 2020, 5, 819-824. [CrossRef]

88. Zeng, J.H.; Liu, Y.X.; Yuan, J.; Wang, F.X.; Wu, W.B.; Li, J.X.; Wang, L.F.; Gao, H.; Wang, Y.; Dong, C.F.; et al. First case of COVID-19 complicated with fulminant myocarditis: A case report and insights. Infection 2020, 48, 773-777. [CrossRef]

89. Kim, I.C.; Kim, J.Y.; Kim, H.A.; Han, S. COVID-19-related myocarditis in a 21-year-old female patient. Eur. Heart J. 2020, 41, 1859. [CrossRef]

90. Escher, F.; Pietsch, H.; Aleshcheva, G.; Bock, T.; Baumeier, C.; Elsaesser, A.; Wenzel, P.; Hamm, C.; Westenfeld, R.; Schultheiss, M.; et al. Detection of viral SARS-CoV-2 genomes and histopathological changes in endomyocardial biopsies. ESC Heart Fail. 2020, 7, 2440-2447. [CrossRef]

91. Basso, C.; Leone, O.; Rizzo, S.; De Gaspari, M.; van der Wal, A.C.; Aubry, M.C.; Bois, M.C.; Lin, P.T.; Maleszewski, J.J.; Stone, J.R. Pathological features of COVID-19-associated myocardial injury: A multicentre cardiovascular pathology study. Eur. Heart J. 2020, 41, 3827-3835. [CrossRef] [PubMed]

92. Mevorach, D.; Anis, E.; Cedar, N.; Bromberg, M.; Haas, E.J.; Nadir, E.; Olsha-Castell, S.; Arad, D.; Hasin, T.; Levi, N.; et al Myocarditis after BNT162b2 mRNA Vaccine against COVID-19 in Israel. N. Engl. J. Med. 2021, 385, 2140-2149. [CrossRef] [PubMed]

93. Bozkurt, B.; Kamat, I.; Hotez, P.J. Myocarditis with COVID-19 mRNA Vaccines. Circulation 2021, 144, 471-484. [CrossRef] [PubMed]

94. Rosner, C.M.; Genovese, L.; Tehrani, B.N.; Atkins, M.; Bakhshi, H.; Chaudhri, S.; Damluji, A.A.; de Lemos, J.A.; Desai, S.S.; Emaminia, A.; et al. Myocarditis Temporally Associated with COVID-19 Vaccination. Circulation 2021, 144, 502-505. [CrossRef] [PubMed]

95. Bang, V.; Ganatra, S.; Shah, S.P.; Dani, S.S.; Neilan, T.G.; Thavendiranathan, P.; Resnic, F.S.; Piemonte, T.C.; Barac, A.; Patel, R.; et al. Management of Patients with Giant Cell Myocarditis: JACC Review Topic of the Week. J. Am. Coll. Cardiol. 2021, 77, 1122-1134. [CrossRef]

96. Shonk, J.R.; Vogel-Claussen, J.; Halushka, M.K.; Lima, J.A.; Bluemke, D.A. Giant cell myocarditis depicted by cardiac magnetic resonance imaging. J. Comput. Assist. Tomogr. 2005, 29, 742-744. [CrossRef] [PubMed]

97. Azarine, A.; Guillemain, R.; Bruneval, P. Different focal delayed gadolinium-enhancement patterns using cardiac magnetic resonance in a case of diffuse giant cell myocarditis. Eur. Heart J. 2009, 30, 1485. [CrossRef] 
98. Sujino, Y.; Kimura, F.; Tanno, J.; Nakano, S.; Yamaguchi, E.; Shimizu, M.; Okano, N.; Tamura, Y.; Fujita, J.; Cooper, L.T.; et al. Cardiac magnetic resonance imaging in giant cell myocarditis: Intriguing associations with clinical and pathological features. Circulation 2014, 129, e467-e469. [CrossRef]

99. Yang, S.; Chen, X.; Li, J.; Sun, Y.; Song, J.; Wang, H.; Zhao, S. Late gadolinium enhancement characteristics in giant cell myocarditis. ESC Heart Fail. 2021, 8, 2320-2327. [CrossRef]

100. Bogabathina, H.; Olson, P.; Rathi, V.K.; Biederman, R.W. Cardiac sarcoidosis or giant cell myocarditis? On treatment improvement of fulminant myocarditis as demonstrated by cardiovascular magnetic resonance imaging. Case Rep. Cardiol. 2012, $2012,647041$. [CrossRef]

101. Birnie, D.H.; Nery, P.B.; Ha, A.C.; Beanlands, R.S. Cardiac Sarcoidosis. J. Am. Coll. Cardiol. 2016, 68, 411-421. [CrossRef] [PubMed]

102. Kouranos, V.; Tzelepis, G.E.; Rapti, A.; Mavrogeni, S.; Aggeli, K.; Douskou, M.; Prasad, S.; Koulouris, N.; Sfikakis, P.; Wells, A.; et al. Complementary Role of CMR to Conventional Screening in the Diagnosis and Prognosis of Cardiac Sarcoidosis. JACC Cardiovasc. Imaging 2017, 10, 1437-1447. [CrossRef]

103. Patel, M.R.; Cawley, P.J.; Heitner, J.F.; Klem, I.; Parker, M.A.; Jaroudi, W.A.; Meine, T.J.; White, J.B.; Elliott, M.D.; Kim, H.W.; et al. Detection of myocardial damage in patients with sarcoidosis. Circulation 2009, 120, 1969-1977. [CrossRef] [PubMed]

104. Patel, A.R.; Klein, M.R.; Chandra, S.; Spencer, K.T.; Decara, J.M.; Lang, R.M.; Burke, M.C.; Garrity, E.R.; Hogarth, D.K.; Archer, S.L.; et al. Myocardial damage in patients with sarcoidosis and preserved left ventricular systolic function: An observational study. Eur. J. Heart Fail. 2011, 13, 1231-1237. [CrossRef] [PubMed]

105. Murtagh, G.; Laffin, L.J.; Beshai, J.F.; Maffessanti, F.; Bonham, C.A.; Patel, A.V.; Yu, Z.; Addetia, K.; Mor-Avi, V.; Moss, J.D.; et al. Prognosis of Myocardial Damage in Sarcoidosis Patients with Preserved Left Ventricular Ejection Fraction: Risk Stratification Using Cardiovascular Magnetic Resonance. Circ. Cardiovasc. Imaging 2016, 9, e003738. [CrossRef]

106. Greulich, S.; Deluigi, C.C.; Gloekler, S.; Wahl, A.; Zurn, C.; Kramer, U.; Nothnagel, D.; Bultel, H.; Schumm, J.; Grun, S.; et al. CMR imaging predicts death and other adverse events in suspected cardiac sarcoidosis. JACC Cardiovasc. Imaging 2013, 6, 501-511. [CrossRef] [PubMed]

107. Brambatti, M.; Matassini, M.V.; Adler, E.D.; Klingel, K.; Camici, P.G.; Ammirati, E. Eosinophilic Myocarditis: Characteristics, Treatment, and Outcomes. J. Am. Coll. Cardiol. 2017, 70, 2363-2375. [CrossRef]

108. Kuchynka, P.; Palecek, T.; Masek, M.; Cerny, V.; Lambert, L.; Vitkova, I.; Linhart, A. Current Diagnostic and Therapeutic Aspects of Eosinophilic Myocarditis. Biomed. Res. Int. 2016, 2016, 2829583. [CrossRef]

109. Li, H.; Dai, Z.; Wang, B.; Huang, W. A case report of eosinophilic myocarditis and a review of the relevant literature. BMC Cardiovasc. Disord. 2015, 15, 15. [CrossRef]

110. Ntusi, N.A.B.; Piechnik, S.K.; Francis, J.M.; Ferreira, V.M.; Matthews, P.M.; Robson, M.D.; Wordsworth, P.B.; Neubauer, S.; Karamitsos, T.D. Diffuse Myocardial Fibrosis and Inflammation in Rheumatoid Arthritis: Insights from CMR T1 Mapping. JACC Cardiovasc. Imaging 2015, 8, 526-536. [CrossRef]

111. Ntusi, N.A.; Piechnik, S.K.; Francis, J.M.; Ferreira, V.M.; Rai, A.B.; Matthews, P.M.; Robson, M.D.; Moon, J.; Wordsworth, P.B.; Neubauer, S.; et al. Subclinical myocardial inflammation and diffuse fibrosis are common in systemic sclerosis-A clinical study using myocardial T1-mapping and extracellular volume quantification. J. Cardiovasc. Magn. Reson. 2014, 16, 21. [CrossRef]

112. Sano, M.; Satoh, H.; Suwa, K.; Nobuhara, M.; Saitoh, T.; Saotome, M.; Urushida, T.; Katoh, H.; Shimoyama, K.; Suzuki, D.; et al. Characteristics and clinical relevance of late gadolinium enhancement in cardiac magnetic resonance in patients with systemic sclerosis. Heart Vessels 2015, 30, 779-788. [CrossRef] [PubMed]

113. Puntmann, V.O.; D’Cruz, D.; Smith, Z.; Pastor, A.; Choong, P.; Voigt, T.; Carr-White, G.; Sangle, S.; Schaeffter, T.; Nagel, E. Native myocardial T1 mapping by cardiovascular magnetic resonance imaging in subclinical cardiomyopathy in patients with systemic lupus erythematosus. Circ. Cardiovasc. Imaging 2013, 6, 295-301. [CrossRef] [PubMed]

114. Postow, M.A.; Sidlow, R.; Hellmann, M.D. Immune-Related Adverse Events Associated with Immune Checkpoint Blockade. N. Engl. J. Med. 2018, 378, 158-168. [CrossRef] [PubMed]

115. Thavendiranathan, P.; Zhang, L.; Zafar, A.; Drobni, Z.D.; Mahmood, S.S.; Cabral, M.; Awadalla, M.; Nohria, A.; Zlotoff, D.A.; Thuny, F.; et al. Myocardial T1 and T2 Mapping by Magnetic Resonance in Patients with Immune Checkpoint Inhibitor-Associated Myocarditis. J. Am. Coll. Cardiol. 2021, 77, 1503-1516. [CrossRef]

116. Zhang, L.; Awadalla, M.; Mahmood, S.S.; Nohria, A.; Hassan, M.Z.O.; Thuny, F.; Zlotoff, D.A.; Murphy, S.P.; Stone, J.R.; Golden, D.L.A.; et al. Cardiovascular magnetic resonance in immune checkpoint inhibitor-associated myocarditis. Eur. Heart J. 2020, 41, 1733-1743. [CrossRef] [PubMed]

117. Banka, P.; Robinson, J.D.; Uppu, S.C.; Harris, M.A.; Hasbani, K.; Lai, W.W.; Richmond, M.E.; Fratz, S.; Jain, S.; Johnson, T.R.; et al. Cardiovascular magnetic resonance techniques and findings in children with myocarditis: A multicenter retrospective study. $J$. Cardiovasc. Magn. Reson. 2015, 17, 96. [CrossRef] [PubMed]

118. Cornicelli, M.D.; Rigsby, C.K.; Rychlik, K.; Pahl, E.; Robinson, J.D. Diagnostic performance of cardiovascular magnetic resonance native T1 and T2 mapping in pediatric patients with acute myocarditis. J. Cardiovasc. Magn. Reson. 2019, 21, 40. [CrossRef]

119. Mavrogeni, S.; Bratis, K.; Georgakopoulos, D.; Karanasios, E.; Kolovou, G.; Pavlides, G.; Papadopoulos, G. Evaluation of myocarditis in a pediatric population using cardiovascular magnetic resonance and endomyocardial biopsy. Int. J. Cardiol. 2012, 160, 192-195. [CrossRef]

120. Martins, D.S.; Ait-Ali, L.; Khraiche, D.; Festa, P.; Barison, A.; Martini, N.; Benadjaoud, Y.; Anjos, R.; Boddaert, N.; Bonnet, D.; et al. Evolution of acute myocarditis in a pediatric population: An MRI based study. Int. J. Cardiol. 2021, 329, 226-233. [CrossRef] 
121. Dubey, S.; Agarwal, A.; Nguyen, S.; Adebo, D. Persistence of Late Gadolinium Enhancement on Follow-Up CMR Imaging in Children with Acute Myocarditis. Pediatr. Cardiol. 2020, 41, 1777-1782. [CrossRef] [PubMed]

122. Baessler, B.; Luecke, C.; Lurz, J.; Klingel, K.; von Roeder, M.; de Waha, S.; Besler, C.; Maintz, D.; Gutberlet, M.; Thiele, H.; et al. Cardiac MRI Texture Analysis of T1 and T2 Maps in Patients with Infarctlike Acute Myocarditis. Radiology 2018, 289, 357-365. [CrossRef] [PubMed]

123. Baessler, B.; Luecke, C.; Lurz, J.; Klingel, K.; Das, A.; von Roeder, M.; de Waha-Thiele, S.; Besler, C.; Rommel, K.P.; Maintz, D.; et al. Cardiac MRI and Texture Analysis of Myocardial T1 and T2 Maps in Myocarditis with Acute versus Chronic Symptoms of Heart Failure. Radiology 2019, 292, 608-617. [CrossRef] [PubMed]

124. Fischer, K.; Obrist, S.J.; Erne, S.A.; Stark, A.W.; Marggraf, M.; Kaneko, K.; Guensch, D.P.; Huber, A.T.; Greulich, S.; Aghayev, A.; et al. Feature Tracking Myocardial Strain Incrementally Improves Prognostication in Myocarditis Beyond Traditional CMR Imaging Features. JACC Cardiovasc. Imaging 2020, 13, 1891-1901. [CrossRef]

125. Polte, C.L.; Bollano, E.; Oldfors, A.; Dudas, A.; Lagerstrand, K.M.; Himmelman, J.; Bobbio, E.; Karason, K.; van Essen, M.; Bergh, N. Somatostatin Receptor Positron Emission Tomography/Computed Tomography in Giant Cell Myocarditis: A Promising Approach to Molecular Myocardial Inflammation Imaging. Circ. Cardiovasc. Imaging 2021, 15, e013551. [CrossRef]

126. Polte, C.L.; Bergh, N.; Oldfors, A.; Hanna, B.; Bollano, E. Cardiac involvement in immune-mediated necrotizing myopathy: Insights from CMR and somatostatin receptor PET/CT. Eur. Heart J. Cardiovasc. Imaging 2021, jeab262. [CrossRef]

127. Lapa, C.; Reiter, T.; Li, X.; Werner, R.A.; Samnick, S.; Jahns, R.; Buck, A.K.; Ertl, G.; Bauer, W.R. Imaging of myocardial inflammation with somatostatin receptor based PET/CT-A comparison to cardiac MRI. Int. J. Cardiol. 2015, 194, 44-49. [CrossRef] 